Beata Karpińska-Musiat

Uniwersytet Gdański

\title{
O dwóch rodzajach krytycznego podejścia do zmiany wśród neofilologów na polskich uniwersytetach
}

\author{
Zmiany nie można wprowadzać na sitę. \\ Zmiana jest procesem i nie przebiega wedtug gotowych schematów. \\ Problemy sa nieuniknione i trzeba je polubić. \\ Zbyt wczesne ustalenie wizji i strategiczne planowanie może Cię zaślepić. \\ Działania indywidualne i zespołowe maja jednakowe znaczenie. \\ Ani centralizacja, ani decentralizacja oddzielnie nie moga funkcjonować. \\ Konieczne sa zwiazki z szerszym środowiskiem. \\ Każdy jest agentem zmiany ${ }^{1}$.
}

\section{Wprowadzenie}

W świetle cytowanych powyżej atrybutów zmiany, prezentowany artykuł stanowi próbę krytycznego spojrzenia na sposób, w jaki środowisko neofilologów i glottodydaktyków postrzega zmianę instytucjonalną oraz paradygmatyczną związaną z wdrażaniem reformy szkolnictwa wyższego. Celem tego tekstu jest wynikająca $\mathrm{z}$ badania sondażowego diagnoza sytuacji powstałej po lub $\mathrm{w}$ trakcie pracy nad dostosowywaniem programów studiów i przedmiotów do wytycznych Krajowych Ram Kwalifikacji, wprowadzonych wchodzącą w życie 1 października 2012 roku, a podpisaną 5 kwietnia br. nowelizacją ustawy z 18 marca 2011 roku dotyczącą prawa o szkolnictwie wyższym² ${ }^{2}$. Celem jest także zaobserwowanie, czy lub na ile posunięcia wygenerowane przez założenia reformy powodują u przedstawicieli tej dyscypliny akademickiej zmianę $\mathrm{w}$ postrzeganiu swej pracy, siebie samych oraz otaczających ich uwarunkowań społeczno-zawodowych. Zagadnienie jest o tyle szczególne, że ta właśnie grupa zawodowa jest niejako podwójnie „naznaczona” w obecnym kontekście zmiany. Z jednej strony wydawałoby się, że jest uprzywilejowana ze względu na wysoką kompetencję

1 Oparte na: M.G. Fullan, The complexity of the change process, [w:] Change forces: Probing the depth of educational reform, Falmer Press 1993, s. 19-41.

2 J. Jabłkowska, A. Różalski, Zmiany w ustawach, Kronika. Pismo Uniwersytetu Łódzkiego 2011, nr 2 (124), s. 7. 
w zakresie języka obcego, pozwalającą na lepsze i sprawniejsze funkcjonowanie na globalnym rynku pracy. Posiada narzędzia, które z założenia umożliwiają przekraczanie kulturowych granic, szerokie wejrzenie w mechanizmy innych kultur (poprzez język), oraz dają poczucie panowania nad światową literaturą w zakresie poszczególnych dyscyplin. W czysto ekonomicznym wymiarze kompetencje językowe przynoszą też zyski płynące z możliwości wykonywania tłumaczeń ustnych czy też pisemnych. $Z$ drugiej jednak strony neofilolodzy zajmują obecnie pozycję niekoniecznie aż tak komfortową. Są w powszechnej opinii uważani za „warsztatowców", mistrzów od języka i jego dydaktyki. Mimo iż studia filologiczne kształcą humanistów (naucza się przecież elementów historii, kulturoznawstwa i literaturoznawstwa), w ostatnich dekadach przełomów lingwistycznych, kulturowych, a co za tym idzie metodologicznych i paradygmatycznych, neofilolog jawi się przede wszystkim jako dobry mówca, znawca i nauczyciel obcego języka. Jednak flagowa niejako kompetencja językowa, nawet wsparta szeroką wiedzą kulturoznawczą i historyczną, straciła już na wartości na dzisiejszym rynku pracy. Na rynku tym, będącym nieuchronnie pod wpływem tendencji neoliberalnych, wiedza ta po prostu jest niewystarczająca, gdyż jest jedynie humanistyczna. Trudno się więc dziwić, że ta sytuacja z reguły nie podoba się przedstawicielom dyscypliny. Zwłaszcza w obliczu narastającego współcześnie konfliktu między zwolennikami oświeceniowej tradycji uniwersytetu, za Kantem podkreślającej rolę uniwersalnego rozumu i wolności³ a tymi, według których XIX-wieczne nadużywanie władzy rozumu doprowadziło do przemocy, chociażby symbolicznej, i zmusiło uniwersytet do poddania się neoliberalnym standaryzacjom. Punktem zapalnym stają się więc wszystkie możliwe procedury, które zmierzają do zmiany sytuacji dawnej, znanej, skutkującej jakością edukacji zupełnie inną aniżeli przyjmowane dzisiaj standardy wytyczane procesem bolońskim i unijnymi przepisami. Pojawia się polemika, czy jakość ta jest gorsza, czy po prostu inna. Pojawia się dysonans w przekonaniach, czy jest to zjawisko negatywne, czy po prostu konieczne i takie, za którym należy podążać. Posługując się słowami Tomasza Szkudlarka, polemizującego na temat edukacji przyszłości i zauważanych w niej tendencji, wariant "nadążania” może się okazać fantazją edukacji dla mas, zaś wariant "ignorowania” - dla elit". Stajemy się obecnie świadkami tworzenia się nowych podziałów na wzór prawie że rewolucyjnego, ponownie powołując się na Szkudlarka, kreowania społeczeństwa wiedzy złożonego z elit "uciekających od przeciętności" oraz mas podążających za nowym hegemonem, jakim jest instytucja prawodawstwa unijnego.

W dużej mierze pożywką dla tego typu kontrowersji staje się profil współczesnych studentów. Od paru już lat zaobserwować można niepokojące postawy młodych rekrutów studiów anglistycznych, którzy będąc ludźmi nowej epoki,

\footnotetext{
3 M. Gdula, Władza krytyczna i siła wyobraźni, [w:] Uniwersytet zaangażowany. Przewodnik krytyki politycznej, Zespół KP, Wydawnictwo Krytyki Politycznej, Warszawa 2010.

4 T. Szkudlarek, Edukacja przysztości: Tendencje, fantazje i scenariusze: http://www.instytutobywatelski.pl/2285/komentarze/edukacja-przyszlosci-tendencje-fantazje-i-scenariusze, dostęp: 31.08.2011.
} 
kompetentnymi medialnie i kulturowo, a nierzadko i społecznie, zderzają się z systemem edukacji wciąż rozdającym bilety do zakorzenionych $w$ przeszłości praktyk i metod. Wielu z tych młodych ludzi przejawia duże zdolności adaptacyjne, a w celu ukończenia formalnej edukacji przestają myśleć, bo ze strony systemu dochodzi do nich głos, że There is no alternative. Zaczynają żyć w pewnej schizofrenii pomiędzy życiem i własnymi możliwościami (nierzadko już pracą w trakcie studiów), a oferowaną w akademii wiedzą, metodą jej podania oraz kompetencjami, które świadczyć mają o jakości wiedzy, ale nie wszędzie i coraz gorzej przystają do potrzeb rynku pracy. Zanim reforma szkolnictwa wyższego formalnie upodmiotowi i upełnomocni studentów (w ich mniemaniu bowiem nie są oni jeszcze należycie upełnomocnieni), i nauczy ich konstruować własną wiedzę, studenci, którzy w życiu pozaakademickim nie raz pełnią już funkcje społeczne, jakie zadziwiłyby starsze pokolenia, są jeszcze wciąż zdziwieni, gdy chce się im udzielić głosu nawet na zwykłych zajęciach i seminariach. Postrzegani przez wielopokoleniową kadrę jako ogół młodzieży aż nadto wyemancypowanej (laptopy, dobory fakultetów, prawa studentów itp.), oni sami czują się złapani w pułapkę systemu edukacyjnego wciąż przypominającego dryl szkolny. Zarzuca się im brak refleksyjności we własnym działaniu, ale zarazem tej refleksyjności się ich nie naucza i nie pozwala jej rozwijać. Według Ryana, studenci aspirujący do bycia nauczycielami często usiłują sprostać zadaniom opartym na refleksji, które skutkowałyby profesjonalnym uczeniem się, zmianą i udoskonaleniem siebie ${ }^{5}$. To wymaga ogromnego wysiłku, ponieważ, jak czytamy za Altrichterem: „profesjonalne uczenie się nie jest po prostu intelektualnym procesem przyswajania i stosowania wiedzy, ale także procesem praktycznego działania, w którym wiedza jest uaktywniana poprzez refleksyjność i rozwój”'6. Czyli powinni móc przekuwać swe ambicje i strategie uczenia się $\mathrm{w}$ działanie, realizować model learning by doing. Okazuje się jednak, że nie jest to takie proste, ponieważ idzie za tym zupełna redefinicja oczekiwanych i kształconych kompetencji, w tym także językowych. Temu zjawisku towarzyszy postawa kadry akademickiej wobec zmiany zarówno w sensie instytucjonalnym, jak i dotyczącym redefinicji treści i poziomu kształcenia. Jest to postawa z gruntu krytyczna, jednak nie w znaczeniu działaniowym, a raczej pasywnym i odrzucającym. Wspomniane $w$ tytule artykułu dwa rodzaje krytycznego podejścia mają znamionować te właśnie dwa znaczenia: krytyczny jako negujący, oraz krytyczny jako radykalnie poszukujący. Celem wywodu prezentowanego poniżej jest być może wskazanie, który rodzaj krytycyzmu na dzień dzisiejszy dominuje w środowisku akademików obcych filologii. Czy, idąc za sugestią Gduli, perspektywa krytyczna, jeśli w ogóle dotykała kiedykolwiek środowisko neofilologiczne, zamknęła się dzisiaj „w błędnym kole oporu i demaskacji” oraz „dawaniu świadectwa”, czy też może zastanawia się ono, jakim językiem

5 T.G. Ryan, The Reflexive Classroom Manager, „A Required Pre-Service Mode Networks", Spring 2007, vol. 9, issue 1 .

6 H. Altrichter, The role of the 'professional community in action research', „Educational Action Research" 2005, 13(1), s. 11; T.G. Ryan, op. cit., s. 2, tłum. z j. angielskiego B. Karpińska-Musiał. 
„poszerzać obszary wolności"7. Może środowisko to ma szansę nie tylko dystansować się i krytykować, ale właśnie poprzez wkodowany szacunek dla innych kultur i inności podążyć za Humboldtowską ideą uniwersytetu badawczego, inkorporującego autonomię badacza i zewnętrzną kulturę, i traktując ją jako łącznik, a nie coś, co dzieli, tworzyć nowe rozwiązania w nowych sytuacjach?

Krytycyzm negujący ma swoje uzasadnienie. Wystarczy powołać się na pamflet Ewy Nawrockiej zamieszczony w "Gazecie Wyborczej” z 5-6 maja 2012, zawierający opinie wygłoszone 18 maja 2012 r. na konferencji UG „Wściekłość i oburzenie. Obrazy rewolty w kulturze współczesnej”. Słuchając przytaczanej przez autorkę argumentacji trzeba istotnie przyznać, że poziom intelektualny oraz językowy (co najbardziej oburza neofilologów) młodzieży aplikującej na filologiczne studia uniwersyteckie obniża się. . To, z czym zmierzamy się na uczelni wyższej, uważane jest za gorzki, niechciany owoc reformy niższych szczebli edukacji, ponieważ to tam następuje „produkcja” maturzystów „oćwiczonych” w testach i myśleniu schematycznym, fragmentarycznym i stechnicyzowanym. Młodzi są szybcy, mniej lub bardziej zdolni, sprawni i ambitni, ale nie w sposób, w jaki oczekuje tego humanistyczna tradycja akademicka. Dotyczy to w dużej mierze tradycji kształcenia językowego, gdyż to w ramach filologii sformułowano założenia kształcenia retorycznego i usiłuje się wykształcić w młodych ludziach sztukę wysławiania się, umiejętności rozumienia tekstów mówionych i czytanych, pisania i dekodowania tekstów. Z tą rozbieżnością między założeniami u źródeł a dzisiejszymi ich "owocami” ma sobie poradzić grono neofilologów. Może byłoby łatwiej to zrobić, gdyby krytyczność w sensie bycia transformacyjnym intelektualistą (transformative intellectual) $\mathrm{H}$. Giroux, miała większą rację bytu $\mathrm{w}$ środowisku. Tymczasem ona dopiero woła o głos i szuka swojego miejsca na wydziałach filologicznych. Słychać na nich niezgodę na rzeczywistość, ale nie wiadomo jeszcze, jakie konkretne działania mogłyby tę niezgodę niwelować lub zaspokajać.

\section{Geneza badania i metoda badawcza}

Ciekawa poziomu owej niezgody na rzeczywistość, a także w imię promowanej przez Ryana refleksyjności akademickiej, przeprowadziłam w lutym i marcu 2012 roku anonimowy sondaż diagnostyczny wśród nauczycieli wydziałów neofilologicznych i filologicznych siedemnastu ${ }^{9}$ uniwersytetów klasycznych w Polsce. Dotyczył on stosunku do wdrażania Krajowych Ram Kwalifikacji dla

\footnotetext{
M. Gdula, op. cit., s. 221-222.

8 E. Nawrocka, Na diabła nam taka edukacja, "Gazeta Wyborcza” z dnia 5-6 maja 2012.

9 Badanie objęło następujące uczelnie: UG, UAM, UJ, UW, UŚ, UMK w Toruniu, UMCS oraz KUL w Lublinie, Uniwersytet Wrocławski, Uniwersytet Łódzki, Uniwersytet w Białymstoku, Uniwersytet Szczeciński, UKW w Bydgoszczy, UWM w Olsztynie, Uniwersytet Opolski, Uniwersytet Zielonogórski, Uniwersytet Rzeszowski.
} 
szkolnictwa wyższego na wydziałach filologicznych i został przeprowadzony drogą internetową. Uzyskane wyniki oraz wypowiedzi respondentów pokazują dość wyraźnie i w sposób zaskakująco emocjonalny, jak trudno jest przeformułować swoje przekonania wobec rzeczywistości akademickiej poddawanej zmianie. Nie jest celem tego artykułu ocena, czy przytaczane wypowiedzi respondentów są uzasadnione, czy nie. Nie poczyniono przy układaniu tego wywiadu pisemnego żadnych założeń. Jego cel jest wyłącznie diagnostyczny i ma pokazać przeżyciowy charakter stosunku do zmiany, bez oceny jej wad lub zalet. $Z$ drugiej strony, badanie to ma też służyć jako przykład działania prowokującego refleksję u nauczycieli, którzy wypowiadając się w ankiecie zostali niejako „wywołani” do namysłu nad sytuacją. Należy bowiem zgodzić się z Lewisem, że samoocena jest dzisiaj popularna w studiach nad edukacją, ponieważ to właśnie udoskonalanie oraz budowanie "od wewnątrz" stanowią szeroko pojęty cel edukacji. Jak pisze na ten temat Ryan: „Jesteśmy zobowiązani kwestionować rzeczywistość w celu analizowania i udoskonalania nauczania, naszych programów dydaktycznych i nas samych. Nauczyciel badacz nieustannie dodaje coś do aktualnej wiedzy i umiejętności poprzez budowanie na tym, co już istnieje. Często te nowe konstrukcje wymagają znaczących modyfikacji, aby pokonać inercję, zastałe struktury i ustalone normy"10. Co więcej, cytowany przez niego Lewis twierdzi dalej, że refleksyjny nauczyciel-badacz przypomina społecznego konstruktora, który konfrontowany jest z koniecznością brania swoich poglądów w cudzysłów, dystansowania się do nich w sposób ciągle podważający ich zasadność, po to, by uniknąć subiektywizmu w ocenie świata i własnego "ja". Taka postawa outsidera wobec własnych przekonań jest bardzo pojemnym i silnym narzędziem krytycznego (w znaczeniu działaniowego) podejścia do efektów własnych posunięć i przemyśleń. Jest narzędziem pozwalającym na rozwój i aktywną zmianę ${ }^{11}$.

Oprócz wyników badania w postaci procentowych obliczeń wybranych odpowiedzi w sondażu, nie pominę też jakościowej analizy wybranych wypowiedzi respondentów, uzyskanych w postaci zamieszczanych przez nich komentarzy do określonych pytań. Są to wypowiedzi, które mówią same za siebie: mamy duży problem i nie wiemy, jak go rozwiązać tak, by wszyscy byli zadowoleni. Niewątpliwie prezentowane przykłady są tylko kroplą w morzu problematyki, jednak poprzez pewną demaskację oporu wobec zmiany wskazują poniekąd na wspomniane dwa rodzaje podejścia krytycznego. Niektóre wypowiedzi nauczycieli bowiem, mimo przeważającej krytyki i oburzenia, pozwalają sądzić, że konieczność zmiany jest dobrze uświadamiana i nawet akceptowana. Szwankują jednak sposób jej wprowadzania, zaplecze infrastrukturalne, a także, co ważne, brak chęci do współpracy zespołowej. Pojęcie kompetencji kluczowych, do których taka współpraca należy, bywa niekiedy zupełnie nierozpoznawalne jako po-

10 T.G. Ryan, op. cit., s. 4, tłum. z j. angielskiego B. Karpińska-Musiał.

11 Y. Lewis, The self as a moral concept, "British Journal of Social Psychology" 2003, 42(2), s. 231; T.G. Ryan, op. cit, s. 4, tłum. z j. angielskiego B. Karpińska-Musiał. 
jęcie teoretyczne. Zaliczane do procesu demokratyzacji edukacji i jej umasowienia (kosztem krytykowanego spadku jakości), kompetencje kluczowe wydają się być tworem obcym niektórym spośród przedstawicieli dyscypliny. Mimo wszystko część respondentów, jakkolwiek nieliczna, wydaje się być gotowa na zmiany, chociażby na razie pozostając $\mathrm{w}$ sferze rezygnacji raczej niż aprobaty i chęci do działania.

\section{Procedura i wyniki badania}

Opinie neofilologów zbadano anonimową ankietą online w lutym i marcu 2012 roku. Uzyskany został zwrot od 188 respondentów. Przedstawione poniżej wybrane pytania i odpowiedzi pogrupowane zostały w dwa bloki tematyczne: pierwszy dotyczący ogólnego stosunku do reformy szkolnictwa wyższego, procesu i elementów zmiany instytucjonalnej rozumianej jako zestaw nowych procedur (5 pytań), oraz drugi, skupiający się na stosunku do zmiany w kontekście już stricte glottodydaktycznym (3 pytania) ${ }^{12}$. Pytania te dotyczyły oceny ogólnej sytuacji w glottodydaktyce $w$ kontekście kompetencji nauczycielskich, własnego postrzegania funkcji i pozycji neofilologa w procesie reformy szkolnictwa wyższego, oraz najbardziej kontrowersyjnego problemu w jej założeniach: obniżenia progu kompetencji językowych wobec kandydatów oraz absolwentów studiów filologicznych. Ostatnie pytanie jest pytaniem podsumowującym i zapytuje o indywi- dualne ustosunkowanie do zjawiska zmiany.

\section{Ogólny stosunek do reformy i zmiany instytucjonalnej}

Krytyka negatywna wobec przejawów wprowadzanej reformy ujawnia się w odpowiedziach na dwa spośród pytań dotyczących formułowania celów i efektów kształcenia $\mathrm{w}$ ramach tworzenia sylabusów przedmiotów akademickich. Pytania te oraz statystykę odpowiedzi zawierają dwa wykresy: Wykres 1. i Wykres 2.

Wykresy te pokazują, że dla ponad połowy badanych konieczność dostosowania się do wytycznych KRK stanowiła utrudnienie i „czasochłonne zadanie, pozbawione większego sensu merytorycznego". Także komentarze umieszczane pod tymi pytaniami wskazują na zdecydowanie negatywny stosunek badanych do procedury wprowadzania Krajowych Ram Kwalifikacji w szkolnictwie wyższym. Krytyka jest na tyle dogłębna, że sięga nawet całego procesu bolońskiego i jego widocznych już, w mniemaniu respondentów negatywnych, efektów. Jako źródło takiego przekonania wskazywany jest np. brak odpowiednich szkoleń dla

12 Cała ankieta o tytule: Proces wdrażania Krajowych Ram Kwalifikacji na Wydziałach Filologicznych oraz Neofilologicznych składała się z 22 pytań. 
pracowników (pracownikom nie zostaty szczegótowo przedstawione cele i istota KRK; dostaliśmy szczątkowe dane, czemu ma to stużyć?).

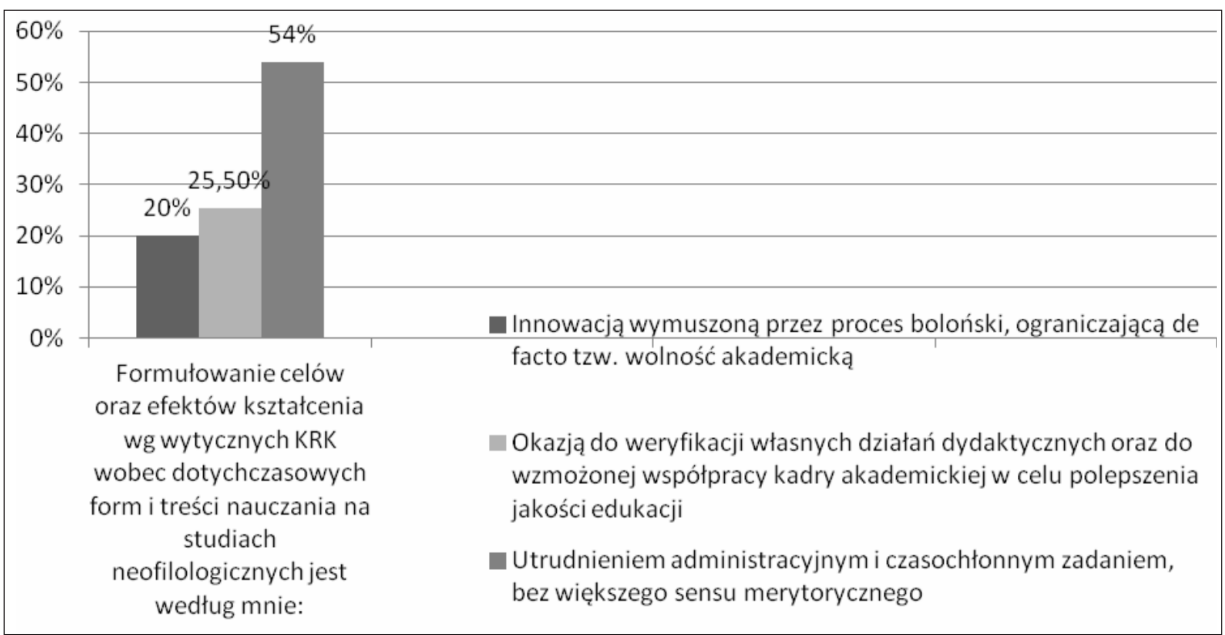

Wykres 1.

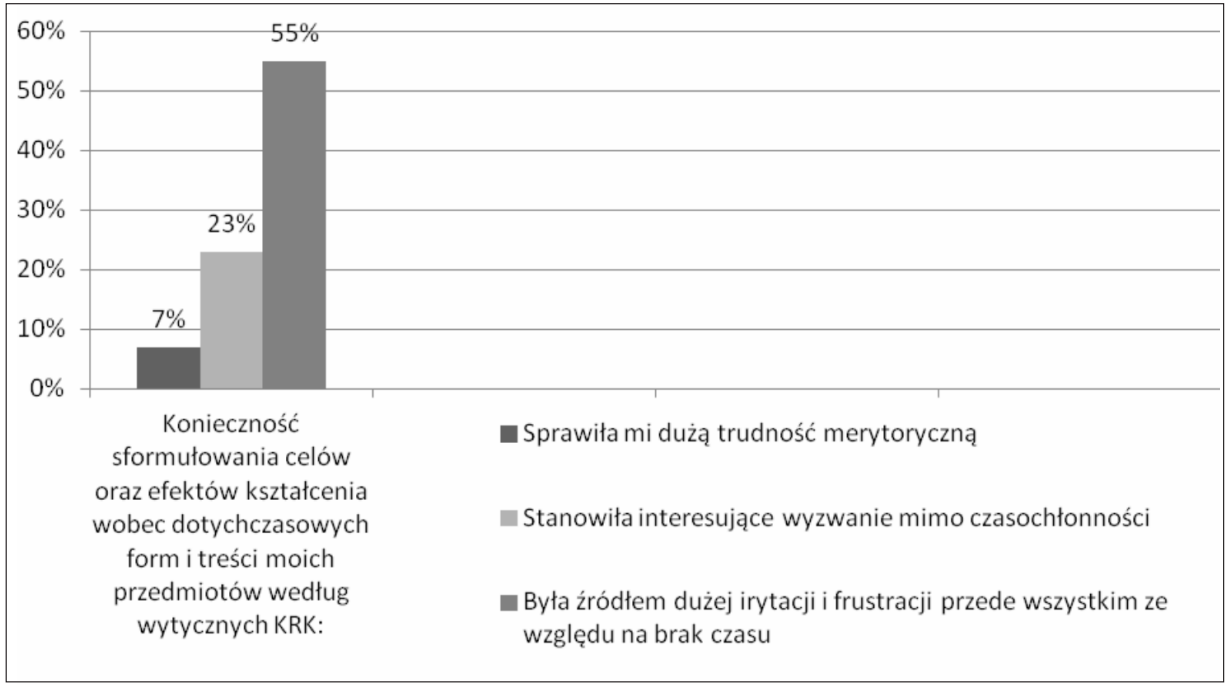

Wykres 2.

Opinie wskazujące na wysoki poziom krytycyzmu zawarte były zarówno $\mathrm{w}$ ostro sformułowanych zdaniach:

To, co ogranicza wolność akademickq (nie "tak zwana!"), to uogólnione, a przez to niestychanie prymitywne kryteria. Poza tym-odwrócenie kolejności działań: najpierw 
opisuje się efekty (CO ABSOLWENT MA UMIEĆ), a potem tok nauczania, który ma do efektów prowadzić. Jak wiadomo, efekty to coś, na czym najlepiej się znaja pyskaci publicyści i PR-owcy, a nie nauczyciele akademiccy, którzy daja wiedzę, podstawe wszelkich UMIEJĘTNOŚCI;

Proces boloński, podobnie jak tzw. wskaźniki skolaryzacji, jest zjawiskiem na dłuższa metę zdecydowanie negatywnym, powodujacym obniżenie poziomu polskiej edukacji (co już teraz wyraźnie widać na neofilologiach). Cóż, rozumiem, że jest to działanie celowe, mające na celu zniszczenie polskiej edukacji, bo wiadomo, że głupszymi łatwiej rzadzić;

jak i łagodniejszych:

Sposób wdrażania KRK, zwłaszcza obowiązek konstruowania sylabusów w trakcie roku akademickiego sprawia, że nowe sylabusy sa uciążiwym obowiazkiem administracyjnym. Mam wiele innych obowiązków, sylabus będę przygotowywać w pośpiechu i na ostatnia chwile.

W wielu sytuacjach wyrażane opinie wskazują na niedoinformowanie pracowników i ich ogólną dezorientację w temacie, co zostało już ujęte powyżej przy okazji braku szkoleń:

Uczestniczyłam w opracowaniu KRK dla studiów I stopnia w naszym zakładzie, potem z poziomu Instytutu tabelki wrócity do nas i wyglądaty zupetnie inaczej; większość osób u nas, także tych opracowujacych, nie ma pojęcia, o co chodzi, inni są szczęśliwi, że nie musieli się w to angażować, informacje byty naciagane i efekt końcowy w naszym zakładzie napawa mnie niezadowoleniem...

Zdarzały się także komentarze wskazujące na niedostosowanie procedur reformy do procesu kształcenia akademickiego, konkretnie na przykładzie właśnie formułowania we wskazany sposób celów i efektów kształcenia:

To komplikuje proces dydaktyczny, ponieważ ogranicza formalny wkład prowadzacego do kopiowania standardowych fraz z szablonu. Zastanówmy się, czy stosowany tu termin "reforma" nie jest nadużyciem semantycznym...;

Komplikuje proces, ale nie dlatego, że zmusza do konsekwencji. Wykładowca może być konsekwentny i bez ram. Proponowane efekty kształcenia nie sa przekładalne na studia akademickie. Kiedyś to szło się na uniwersytet po wiedzę, bo "umiejętności", czyli zgodnie z udostępniona nam definicja "zdolność do stosowania wiedzy i rozwiązywania problemów" kandydat posiadat, zaś bez "kompetencji społecznych" nikt by się na studia nie dostat.

Zaistniały też takie, które krótko i rzeczowo prognozowały przyszłość reformy:

Krótkie uzupetnienie: reforma (jeśli się powiedzie) zlikwiduje rzetelna wiedzę i prawdziwie pogłębiona refleksje - zostana tytuty, stopnie i sprawozdania (ale będą za to tadnie, w uporząd-kowany sposób napisane).

Ogólne niedoinformowanie oraz czysto organizacyjne utrudnienie prowadzonej w ciągu roku dydaktyki zdaje się być dominującym argumentem przeciwko KRK. 
Uwidacznia się bowiem w niektórych wypowiedziach (co prawda mniej licznie) pewne przekonanie, że gdyby nie one, to sama procedura ma jednak jakiś sens i pozytywny wydźwięk. Te właśnie nieliczne opinie pozwalają sądzić, że przy lepszej organizacji procesu, skuteczniejszej instrukcji oraz być może większej ilości czasu do dyspozycji, formułowanie sylabusów nie wzbudziłoby u respondentów tylu negatywnych emocji.

Ogólnie jest w tym sens, ale forma tych opisów jest zdecydowanie zbyt skomplikowana, zagmatwana i niejasna dla przeciętnego odbiorcy - tylko przeszkolony urzędnik jest $w$ stanie przedrzeć się przez taki opis;

Jest to okazja także do uporządkowania pewnych spraw, ale chyba nie jest to najlepszy z możliwych sposobów takiej weryfikacji.

Dobrze jest zastanowić się nad działaniami dydaktycznymi, ale konstruowanie tabelek do tego nie zmusza. Byłoby to owocne, gdyby zatrzymato się na etapie ustalenia, jaka wiedzę i umiejętności powinien posiadać student po ukończeniu danego kursu.

Na niewielką dozę optymizmu pozwala jeden wynik z Wykresu 1., w którym pojawiło się ponad $20 \%$ odpowiedzi sugerujących, że jednak KRK było pewną okazją do weryfikacji własnych działań dydaktycznych oraz wzmożonej współpracy między kadrą akademicką, podobnie jak i ponad 20-procentowy wynik odpowiedzi na Wykresie 2., mówiących, iż było to interesujące wyzwanie pomimo czasochłonności.

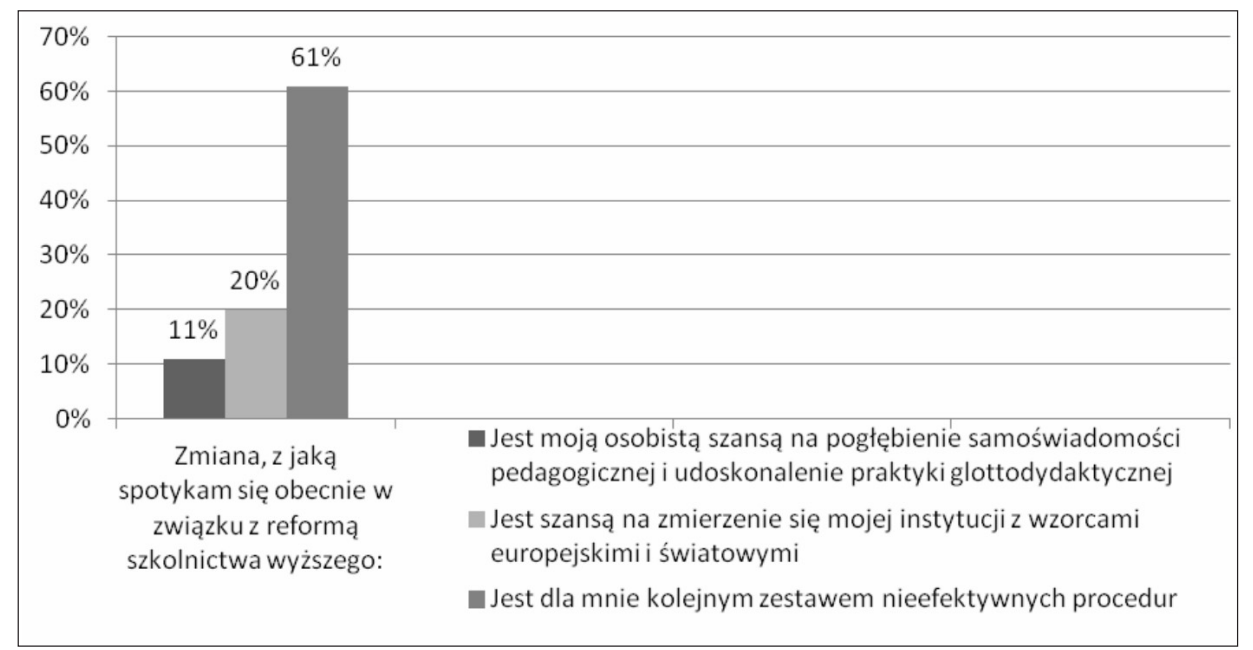

Wykres 3.

Kolejne pytanie kwestionariusza z zadziwiającą konsekwencją wskazuje na zbliżony procentowy układ odpowiedzi pokazujących krytykę negatywną. Tym razem dotyczyło zmiany $w$ kontekście instytucjonalnym (czy jest ona postrzega- 
na jako zmierzanie ku wzorcom europejskim) oraz czysto indywidualnym (czy jest szansą na pogłębienie własnych kompetencji).

Jak widać, ponownie większość respondentów (ponad 60\%) uważa zmianę za „kolejny zestaw nieefektywnych procedur". Dla 20\% jest to jednak szansa na podążanie za europejskimi wzorcami, ale tylko dla $11 \%$ reforma jest uważana za szansę osobistego rozwoju zawodowego. Dodawane komentarze potwierdzają ten niewysoki wynik ostatniej odpowiedzi, opisując zmianę w następujący sposób:

Jest kolejnym etapem dezintegracji polskiej kultury akademickiej;

Będzie powodowała radykalne obniżenie poziomu wiedzy studentów, którzy potem zostanq nauczycielami;

Pogłębia również frustrację i chęć opuszczenia polskiego środowiska akademickiego;

Będq one bardzo efektywne [zmiany - przypis aut.], jeśli chodzi o zniszczenie środowiska myśli krytycznej na uniwersytetach.

Krytyczny jest też komentarz: ślepo i bezrefleksyjnie jesteśmy zapatrzeni w „światowe wzorce". Tytułowe światełko w tunelu, poszukiwane we wspomnianych wyżej $20 \%$ odpowiedzi o postrzeganiu zmiany jako szansy, może miałoby możliwość zabłyśnięcia w komentarzach typu: Idea wprowadzania nowych modeli jest jak najbardziej inspirujaca, problem stanowi SPOSÓB JEJ WDRAŻANIA, z biurokracja przesłaniająca sens catego przedsięwzięcia; lub też: Z jednej strony jest szansq, ale przy minimalnych wymaganiach wobec studenta $i$ obniżeniu progu wymagan staje się nieefektywna. Widać jednak, że administracyjna strona reformy przesłania jej blask przynajmniej na moment obecny. (Mogło być gorzej, sa pewne pozytywne aspekty, ale zasadniczo reforma kuleje).

W grupie pytań o ogólny stosunek do zmiany powodowanej reformą, znalazło się też jedno zapytujące o nowy system składania wniosków o granty badawcze do Narodowego Centrum Nauki. Jest to jedno z nielicznych pytań, które uzyskało najwyższy procent (41\%) odpowiedzi uznających nowy system za „zrozumiałą konieczność ze względu na sposób finansowania badań". Trudno ocenić, czy jest to postawa optymistyczna, czy po prostu adaptacyjna. Zwłaszcza, że bliski wynik w wysokości $31 \%$ uzyskała odpowiedź, że system ten jest „utrudnieniem proceduralnym bez wymiernych korzyści", czyli wpisująca się w krytykę negatywną. Podobny wydźwięk mają też zamieszczone komentarze, które wydają się akcentować w tym przypadku finansowy aspekt tej procedury. (Uważam, że granty badawcze nie moga zastapić podwyżek, które należą się pracownikom naukowym). Odpowiedzi na to pytanie kształtowały się następująco:

Warta zauważenia jest także uwaga na temat kompetencji potrzebnych do złożenia takiego wniosku o grant, podkreślająca, że tak naprawdę należałoby to zadanie powierzyć specjalistom. Konieczność zachowania wszystkich reguł oraz wymogów wniosku badawczego w postaci wypełniania około sześćdziesięciu stron formularza istotnie jest zadaniem wymagającym i czasochłonnym, do które- 
go nie każdy może czuć się predysponowany. Taka opinia wyłania się np. z komentarza:

Uważam, że ten sposób może dziatać efektywnie, o ile instytucje zdecydują się zainwestować w zatrudnienie "doradcy grantowego"; pomyst, by każdy oddzielnie studiowat ministerialne reguty i przedzierał się przez gąszcz biurokratyczny, uważam za kompletnie absurdalny. Mam wizję podziału kadry naukowej na dwie grupy: 1/ zajmujących się pozyskiwaniem grantów i 2/ zajmujących się pracą naukową.

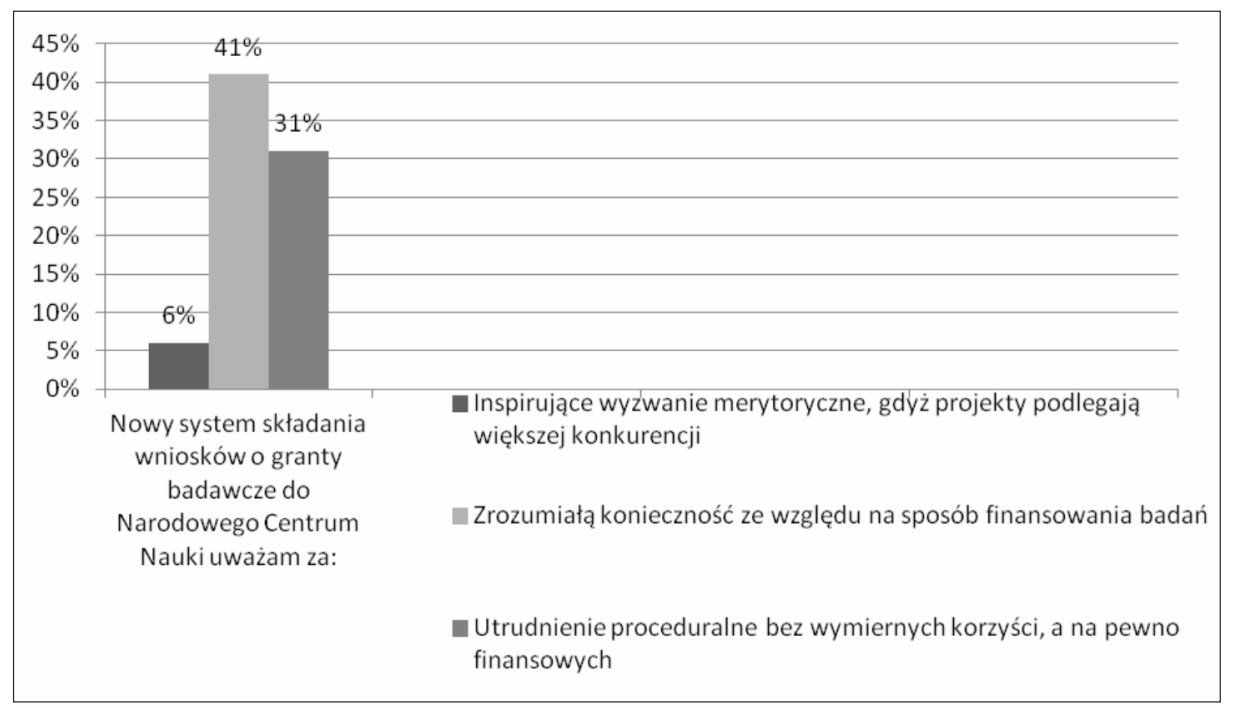

Wykres 4 .

Zaledwie jedna osoba zamieściła komentarz: Inspirujące wyzwanie, ale zbyt radykalnie obniżające możliwości finansowania elementarnych potrzeb jednostki.

\section{Stosunek do zmiany w kontekście glottodydaktycznym}

Ponieważ kontekst artykułu oraz całego badania jest przede wszystkim glottodydaktyczny, część pytań kwestionariusza dotyczy zagadnień związanych bardziej bezpośrednio z dydaktyką języków obcych. Na poczet tego tekstu przytoczone zostaną trzy z nich: jedno pytające o to, jaka jest według badanych relacja między teorią glottodydaktyki a praktyką, drugie sondujące percepcję swojej pozycji w procesie reformy jako neofilologa oraz trzecie, dotykające kluczowej kwestii obniżania oczekiwanego poziomu kompetencji wobec studenta studiów filologicznych. Pośród komentarzy udzielonych przy okazji tego pytania przede wszystkim uderzało mniej lub bardziej bezpośrednie przyznanie się respondentów, że nie do końca jest dla nich jasne, o co chodzi w sformułowaniu 
„teoretyczny opis kompetencji" lub „opracowania teoretyczne" dotyczące zagadnień glottodydaktyki. (Nie wiem, na czym opiera się ów 'teoretyczny opis' i skąd się wziąt. Chętnie bym przeczytała, ale ankieta nie podaje danych bibliograficznych; Nie mam pojęcia, czym są kompetencje kluczowe, a czym przedmiotowe). Być może rzeczywiście jest to sformułowanie zbyt ogólne. Winna zatem jestem tutaj wyjaśnienie, że chodziło po prostu o literaturę przedmiotu dotyczącą rozwoju badań w glottodydaktyce, zagadnień teoretycznych, opisu kompetencji nauczycieli, uaktualniania metodyki nauczania oraz rosnącej konieczności podążania tej dyscypliny za definiowanymi specyficznymi wymaganiami uczniów szczególnie uzdolnionych, lub też tymi z trudnościami w uczeniu się.

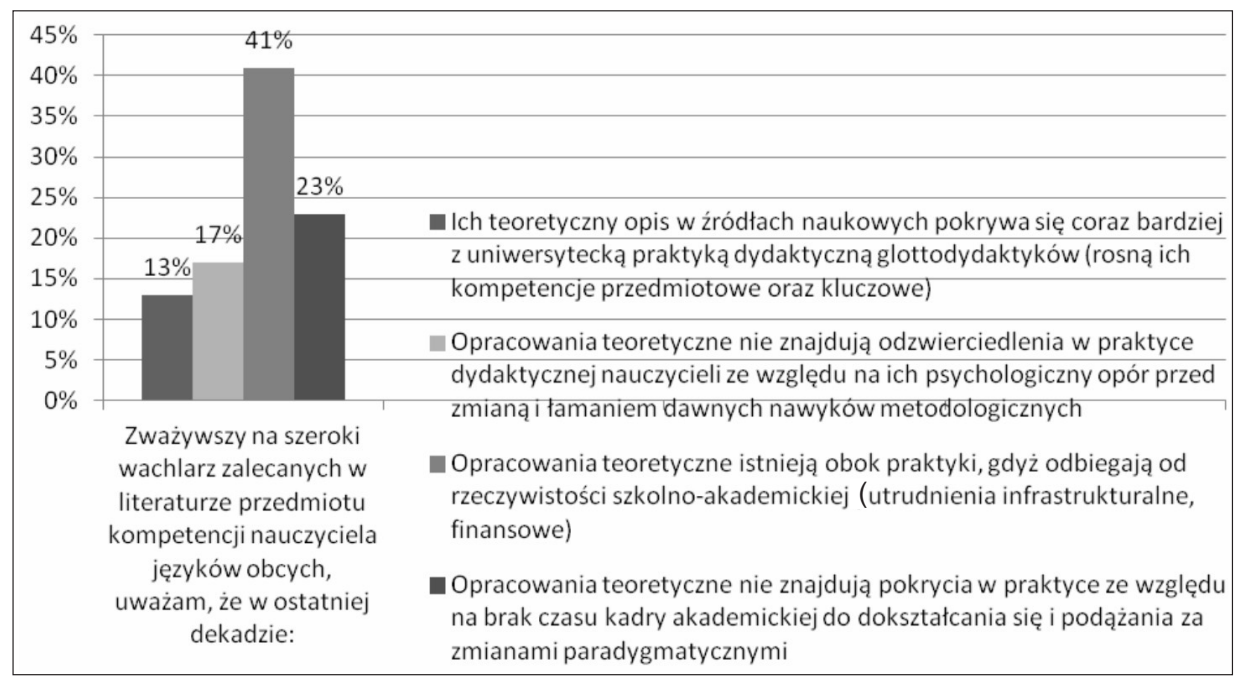

Wykres 5.

Uznałam, że literatura przedmiotu wskazuje na sytuacje i rozwiązania pożądane, godne aplikacji i naśladowania. Pytania o relację teorii z praktyką miały na celu poznanie zdania badanych na temat przyczyn ewentualnych rozbieżności między nimi lub jej braku. Jak się okazało, największa liczba osób (41\%) uważa, że teoria odbiega od praktyki ze względu na finansowe i infrastrukturalne problemy rzeczywistości szkolno-akademickiej. Jako drugi w kolejności pojawił się argument braku czasu na dokształcanie się kadry, a zaledwie $13 \%$ uznało, że rozwój teorii pociąga za sobą dobre praktyki dzięki rosnącym kompetencjom kluczowym i przedmiotowym. Taki wynik wydaje się być ostrzem krytyki wymierzonym przez nauczycieli przeciwko sobie samym i cenną formą autorefleksji. Służą jej także zamieszczone uwagi potwierdzające powyższe wyniki:

Nauczyciele języków obcych coraz mniej sq humanistami, a coraz bardziej zwyktymi wyrobnikami, którzy nie potrafiq zrozumieć dtuższego artykutu publicystycznego, a tym bardziej akademickiego; 
Nie czytam literatury przedmiotu.

Szczególnie ostatnie zdanie powinno wzbudzić niepokój i refleksję na temat przyczyn takiego stanu rzeczy. Przy okazji tego pytania warto także zwrócić uwagę na sięgający zaledwie $20 \%$ wynik odpowiedzi wskazującej na zauważaną rozbieżność między teorią a praktyką z powodu psychologicznego oporu przed zmianą u nauczycieli w ogóle. Można chyba spojrzeć na ten wynik pozytywnie, na zasadzie szklanki prawie pustej, a nie niezupełnie pełnej. Oznaczać by to mogło bowiem, że respondenci bardziej czują się uwikłani w okoliczności zewnętrzne i od nich niezależne, aniżeli odczuwają osobistą niechęć lub opór przed nowymi rozwiązaniami. Pozwala to znowu lekko zajaśnieć światełku w tunelu, jeśli za takowe uważać otwartość na przekształcenia formalne i administracyjne zmierzające do ustalenia postanowień reformy. Mimo wszystko jednak jej potencjalne korzyści są nadal zbyt odległe i nie pozwalają zniwelować dojmującej goryczy, jaka wyziera np. z poniższego komentarza:

Jeżeli mówimy o nauczycielu na poziomie akademickim, cały problem tkwi w tym, że nic go nie motywuje do dobrej pracy i nikt, zupetnie nikt go nie kontroluje. Wystarczy być na zajęciach, trzeźwym i obecnym (gdy jest się starszym wykładowca). Osoby na etatach naukowych musza zrobić dużo, by się utrzymać, dużo w dziedzinie nauki... W kwestii dydaktyki za nic nie dostaje się punktów. Poza tym wszyscy musza zarabiać... przy takich pensjach wszyscy pracujemy na 3 etatach... To jak mamy pracować dobrze? Jak ma nam zależeć, by się kształcić, zmieniać, czytać w dziedzinie, za która jest zero punktów?! To bardzo smutne (bo jak wyksztatcimy naszych studentów, taki potem będziemy mieli naród), ale tak jest.

Kolejne pytanie miało na celu sprawdzenie, czy badani respondenci w jakikolwiek sposób postrzegają swoją pozycję neofilologa jako inną od innych dyscyplin humanistyki lub też nawet pozostałych nauk. Inną ze względu na kompetencje językowe i przez to teoretycznie ułatwiony dostęp do tekstów innych kultur. Jak pokazuje Wykres 6., dominowało przekonanie (44\% odpowiedzi) o braku znaczenia przedmiotowych kompetencji neofilologa dla procesu wdrażania KRK oraz sprostania pisaniu sylabusów. Potwierdzały to zamieszczane komentarze o następującej treści:

Nie mam na nic wptywu, więc moja znajomość języka nie jest do niczego potrzebna; Oczywiście zmiana merytoryczna NIE MUSI korelować ze znajomościa języków obcych;

Nie widzę merytoryczności zmiany;

Bez znaczenia, bo nie ma tu żadnego meritum. Wbrew pseudo-reformie, będziemy robić swoje, tzn. ksztatcić humanistów, którzy będq w stanie rozumieć rzeczywistość międzyludzka, kulturowa i polityczna, nas otaczająca. Tylko tacy potrafia podejmować właściwe wybory obywatelskie i ekonomiczne;

Dla umystu naukowego nie powinno to mieć znaczenia (znajomość języków jest oczywista). 


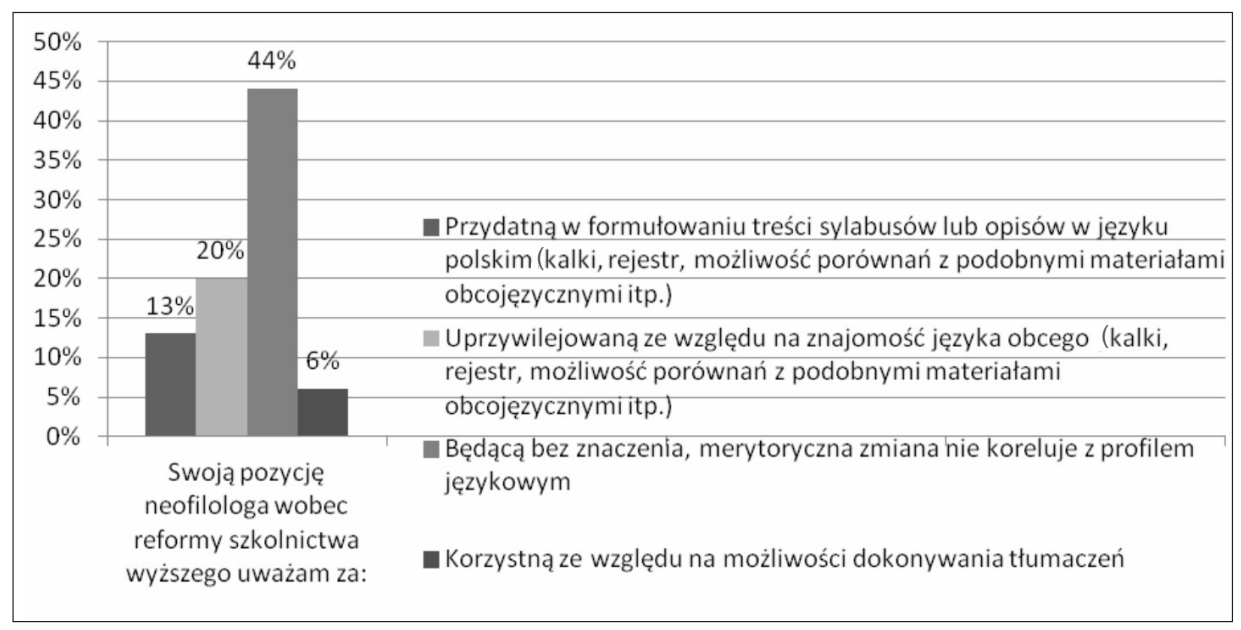

Wykres 6.

Mimo wszystko jednak $20 \%$ ankietowanych uważa tę pozycję za uprzywilejowaną, a niewielu (6\%) „korzystną ze względu na możliwości dokonywania tłumaczeń". Istotny jest jeden z komentarzy: Nie tyle znajomość języka jest ważna, co znajomość systemów kształcenia w innych państwach europejskich, gdzie ten system już działa od lat, który słabym światłem, ale rozpala znowu małe światełko i teoretycznie wskazuje kierunek poszukiwania rozwiązań dla trudnej sytuacji w polskim szkolnictwie wyższym. Opinia ta nie sugeruje, czy inne kraje odniosły sukces, czy porażkę, ale proponuje zrozumienie mechanizmu i próbę odniesienia sposobu jego działania do rodzimej problematyki. Jest to, wydaje mi się, dobry przykład kiełkującego krytycyzmu działaniowego, opozycji wobec opozycji, jest to propozycja zarzucenia wędki w kierunku krytycznego spojrzenia na własne „wody”.

Chyba najwięcej emocji oraz rozbudowanych komentarzy wywołało pytanie dotyczące konieczności formalnego obniżenia poziomu językowego wymaganego od studentów na początku oraz na końcu studiów. Praktyczna nauka języka obcego na neofilologiach od zawsze stanowiła bardzo kluczowy element programu studiów i świadczyła o klasie oraz jakości studiów językowych. Dlatego też obniżenie wymagań w tym zakresie jest najbardziej krytykowanym rezultatem umasowienia edukacji uniwersyteckiej. Za niesłuszne uważa ten fakt $63 \%$ ankietowanych, podczas gdy tylko dla $14 \%$ jest to posunięcie słuszne. Chcąc zinterpretować ten wynik należałoby chyba skupić się na tych właśnie kilkunastu procentach, gdyż wskazują one na nieliczny, ale jednak istniejący odsetek osób uznających zejście z poziomu dotychczasowych wymagań za słuszny. Jakie mogą być przyczyny takiej opinii? Może jest nią np. przeniesienie nacisku z kompetencji przedmiotowych na kluczowe, co jest ogólnoeuropejską i światową tendencją? Może osoby te upatrują w umasowieniu edukacji perspektywy podniesienia jakości funkcjonowania społeczeństwa sensu largo? 
Niestety większość komentarzy potwierdza ostrą krytykę takiego stanu rzeczy:

Straszne!; Niestuszne i karygodne; Jest to kompromis wobec ruiny szkolnictwa średniego; Tragiczne i żałosne;

Jest to upadek filologii angielskiej - cofnięcie się do czasów przedwojennych i zrównanie poziomu języka absolwenta z poziomem uzdolnionego licealisty. Na anglistyce będq wytacznie kandydaci niewiele lepsi od początkujacych.

Spora część badanych poświęciła czas na bardziej rozbudowane uwagi, opisujące postrzeganą rzeczywistość i motywy, które doprowadziły do obecnej sytuacji:

Od lat zauważa się postępujące pogorszenie poziomu opanowania języka i ogólnej wiedzy filologicznej studentów. Filologia powoli staje się trochę bardziej zaawansowanym kursem językowym, bo przecież niczego już od studentów nie można wymagać. KRK nie przewidziata jednej kompetencji, którą uniwersytet kształcit: student kiedyś potrafit myśleć. Dzisiaj ma być praktycznie przygotowany do pracy;

Jako metodyk szkoły językowej obserwuje staty spadek kompetencji jezzykowych nauczycieli rozpoczynających pracę w zawodzie, co z kolei przektada się na obniżenie poziomu ksztatcenia uczniów;

Te wymagania dotycza wszystkich studentów studiów humanistycznych (np. historii czy filozofii), którzy na tym poziomie powinni znać jakiś język obcy (zazwyczaj angielski). Na filologiach efekty kierunkowe powinny wskazywać na wyższy poziom wyjściowy (w przeciwnym razie godzimy się na to, że kształcenie językowe na filologii jest porównywalne z kształceniem językowym na filozofii, gdzie studenci maja lektorat $z$ j. obcego).

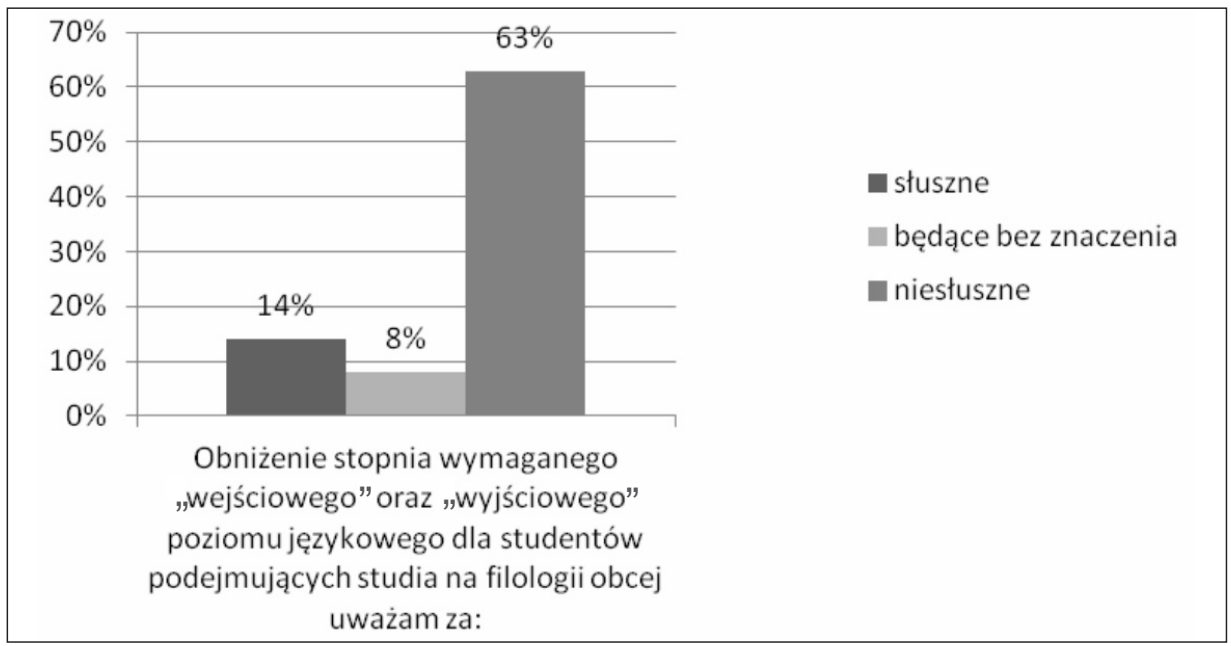

Wykres 7. 
Na uwagę zasługuje jeden komentarz, w którym poruszony został problem ogólnego spadku formy intelektualnej młodych ludzi i trudność, jaką stanowi próba "wyprodukowania" z nich w ciągu zaledwie trzech lat nauczycieli języka obcego:

To jest w ogóle temat rzeka - po pierwsze, poziom ogólny studentów w ciąu ostatnich dwóch lat obniżyt się diametralnie, są to młodzi ludzie, którzy nie potrafią się wypowiadać nawet w języku ojczystym, nie czytaja ksiażek (przychodząc na filologię dziwią się, że trzeba czytać książki), nie potrafia się uczyć!!! Po drugie, w obecnej sytuacji, gdy mamy tylko trzy lata na nauczenie ich języka i uczynienie z nich nauczycieli, przy jednoczesnym obniżeniu liczby godzin przeznaczonych na zajęcia, nasza praca i wszelkiego rodzaju wymogi sa absolutna abstrakcją. Cały czas zastanawiam się, kiedy ci, którzy formulują te fantastyczne wymogi, zejda na ziemię i zainteresują się rzeczywistym stanem edukacji w Polsce.

Pytanie to wywołało jednak także sporo reakcji innego typu, mianowicie pewnego rodzaju rezygnacji i akceptacji nieuniknioności opisywanego zjawiska. Przy całej jego kontrowersyjności, wielu ankietowanych przyznaje, że jest ono niesłuszne, ale niestety konieczne, lub też niesłuszne ze względów merytorycznych, ale zrozumiałe ze względów ekonomicznych, gdyż inaczej nie mielibyśmy studentów. Zdroworozsądkowe podejście ujawnia się w komentarzu:

Takie obniżenie jest po prostu konieczne, ponieważ w ostatnich latach przy średnio 100 przyjętych osobach 15 znajdowało się na poziomie $C 1$, a następnie poziom spadał aż do poziomu A0. Stojąc przed wyborem nieprzyjęcia 90\% kandydatów i zwolnienia 90\% pracowników a obniżenia poziomu wniosek nasuwa się sam.

Pragmatyzm natomiast i utylitarne podejście ujawnia się w uwadze typu:

Jest niż demograficzny i nie mamy wyjścia, jeśli postawimy na jakość na dzien dobry, zabraknie nam ilości... Przecież wszyscy chcemy mieć pracę.. Dlatego przyjmujmy wszystkich $i$ stawiajmy na postęp... Oczywiście bez przesady, ale stawiajmy raczej na postęp niż na to, że wykształcimy absolwentów Oxfordu.

\section{Własna tożsamość wobec zmiany}

W ogólnym, podsumowującym ankietę pytaniu o percepcję własnego ustosunkowania do zmiany, prawie połowa badanych uznała, że do zmian podchodzi co prawda sceptycznie, ale jednak „uważnie i sumiennie za nimi podąża”. Co więcej, także $40 \%$ badanych "lubi nowe wyzwania zawodowe i z latwością adoptuje się do nowo stawianych wymagań", a tylko $1 \%$ uważa się za osoby nielubiące zmian. Wyniki te przedstawia Wykres 8.

Powyższe odpowiedzi wydają się stać w sprzeczności z opiniami wyrażanymi we wcześniejszych pytaniach, które to opinie z gruntu negowały zachodzącą obecnie zmianę. Jednak można zaryzykować stwierdzenie, że po prostu ta akurat zmiana i sposób jej przeprowadzania (prawdopodobnie ten właśnie aspekt) wywołują opór i krytykę, nie zaś zmiana jako czyste zjawisko oznaczające rozwój 
i nowe wyzwania. Spoglądając na przytoczone we wstępie tego artykułu aspekty zmiany sformułowane przez Fullana, należy pamiętać, że zmiana jako wielka niewiadoma będzie zawsze wywoływać opór. $Z$ drugiej jednak strony, „każdy jest agentem zmiany", zatem własny wkład w jej proces może przynosić satysfakcję i poczucie sprawstwa. Być może tak właśnie myślał jeden z respondentów, komentując swoją odpowiedź następująco:

Pod warunkiem, że widzę SENS w proponowanych zmianach. Dotychczasowe poczynania związane z reforma budza moje nieustanne zadziwienie - czy ludzie, którzy pracuja nad reforma, mają choć cień pojęcia o pracy filologa, jej warunkach, specyfice??? Śmiem wątpić. Jeśli zatem widzę ciekawe wyzwanie, to je podejmuję - ciagły rozwój $i$ samoksztatcenie to dla mnie niezbędny warunek bycia naukowcem. Ale stosunek ministerstwa do humanistów i humanistyki w ogóle... brak stów.

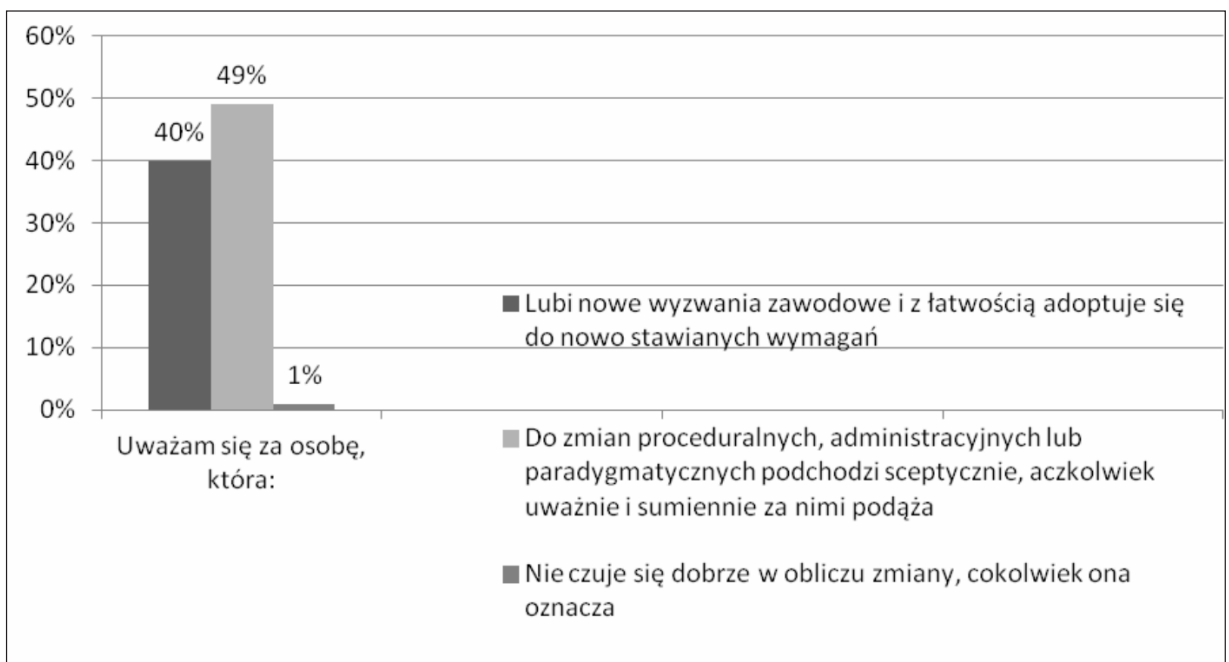

Wykres 8 .

\section{Podsumowanie i wnioski}

Prezentowane fragmenty badania obrazują opinie reprezentantów polskiej neofilologii na temat wdrażanych elementów reformy szkolnictwa wyższego. Mimo planowanej bezzałożeniowości badania próbowałam pośród wypowiedzi respondentów doszukać się jakiegokolwiek cienia wątpliwości wobec dominującej krytyki negatywnej, stwierdzenia, że może jednak reforma nie niesie wyłącznie degradacji polskiej tradycji akademickiej i że można spojrzeć na nią jak na przebudowę rusztowania wokół nowej budowli. Innymi słowy, usiłowałam wyodrębnić dwa rodzaje krytycyzmu, z których jeden opierałby się nie jedynie na kontestacji, a na innych pobudkach, aniżeli wyłącznie przerażenie spadkiem ja- 
kości kształcenia powodowanym najczęściej trudną sytuacją ekonomiczną uniwersytetów i nauki polskiej. Być może na zaakceptowaniu, że ta jakość powinna być traktowana jako inna, a nie gorsza. Opisują ją inne parametry, kryteria stosowalności, poparte istniejącymi już opracowaniami naukowymi (English Lingua Franca Core ${ }^{13}$, metodyka nauczania języka angielskiego jako języka międzynarodowego - International English ${ }^{14}$ etc.). Także postawa i kompetencje glottodydaktyka jako Międzykulturowego Użytkownika Języka (Intercultural Speaker) zmieniły się od czasu ideału aspirującego do bycia nieomal native-speakerem ${ }^{15}$.

Wnioski, jakie nasuwają się w związku z wynikami ankiety, nie pozwalają na razie sądzić, że środowisko neofilologów $\mathrm{w}$ Polsce zaakceptowało nowe reguły działania. Przy wysokiej świadomości teoretycznej, rozbudowywanej w publikacjach naukowych, wciąż pojawia się problem z przekładaniem teorii na praktykę. Skrzętnie rozbudowywany jest zakres wiedzy o nowoczesnej szkole i metodach nauczania języków obcych w powiązaniu z kulturą, ale wciąż panuje przekonanie, że przekazanie tej wiedzy młodym adeptom sztuki nauczycielskiej, jak również nauczenie ich języka na miarę brytyjskiego Received Pronunciation stanowią trzon działania glottodydaktycznego. Jak wynika z badania, większość neofilologów w Polsce uważa, w imię tradycji Kantowskich, że przyjmując tę wiedzę i umiejętności, młode pokolenia mają budować jakość intelektualną (i językową) nieustępującą tej sprzed kilkunastu lub kilkudziesięciu lat. Na pewno w postawie tej przebija dawna nuta krytyczna, głos uniwersytetu, który świadom konieczności transformacji, walczy jeszcze o utrzymanie dawnego status quo. Zarazem jest to już także nuta sentymentalna. Prawdą jest, że tradycyjne kształcenie filologiczne, jeśli przyjąć za nie edukację sprzed reformy szkolnictwa w 1989 roku, jakie większość z respondentów pamięta, to przede wszystkim kształcenie humanistyczne, a niejako przy okazji kuźnia mówienia w obcym języku. Może dlatego też należałoby się zgodzić z Klausem Bachmannem, który pisze w kontekście krytyki tendencji neoliberalnych, że współcześnie po pierwsze „uczelnie nie są w stanie

13 Np. J. Jenkins, The Phonology of English as an International Language, Oxford University Press, Oxford 2000; J. Jenkins, A sociolinguistically based, empirically researched pronunciation syllabus for English as an International Language, Applied Linguistics 2002, 23, s. 83-103.

${ }_{14}$ Np. B.B. Kachru, Standards, Codification and Sociolinguistic Realism: the English Language in the Outer Circle, CUP, Cambridge 1985; B. Seidlhofer, A concept of International English and related issues: From 'real English' to 'realistic English'?, Language Policy Division, Council of Europe, Strasbourg 2003; A. Mauranen, E. Ranta (eds), English as a Lingua Franca: studies and findings, Cambridge Scholars Publishing 2005.

15 Np. E. Bandura, Nauczyciel jako mediator kulturowy, Wyd. Tertium, Kraków 2007; L. Bredella, For a Flexible Model of Intercultural Understanding, [in:] G. Alred, M. Byram, M. Fleming, Intercultural Experience and Education, Clevedon, Multilingual Matters, 2003, s. 31-49; M. Byram, Intercultural Communicative Competence: the Challenge for Language Teacher Training, [in:] British Studies: Intercultural Perspectives, A. Mountford, N. Wadham-Smith (eds), Longman 2000; M. Byram, K. Risager, Language Teachers, Politics and Cultures, Clevedon, Multilingual Matters, 1999; B. Karpińska-Musial, Intercultural Speaker jako odpowiedź na wspótczesne wyzwania globalnego społeczeństwa wiedzy. Analiza procesu nabywania kompetencji międzykulturowej przez ucznia i nauczyciela języków obcych, [w:] Komunikacja językowa w społeczeństwie informacyjnym, red. J. Krieger-Knieja, U. Paprocka-Piotrowska, Towarzystwo Naukowe KUL, Lublin 2005, s. $261-272$. 
przewidzieć, jak się rozwinie rynek pracy za 4-5 lat, a nawet gdyby mogły, i tak nie byłyby w stanie przyuczyć studentów do konkretnych zawodów, ponieważ personel uniwersytecki nie ma ani wiedzy, ani umiejętności, aby kształcić w konkretnym zawodzie"16. Akademicy nie uważają siebie za mistrzów przyjmujących u siebie czeladnika lub praktykanta przyuczającego się do zawodu tłumacza lub nauczyciela (pomimo takowego celu studiów 1 stopnia). Wciąż spora ich część twierdzi, że „od absolwenta wyższej uczelni wymaga się posiadania jakiegoś obowiązującego minimum wiedzy encyklopedycznej w swojej dziedzinie"17. Bachmann krytykuje jednak zarazem tradycyjną, elitarną formę kształcenia uniwersyteckiego, twierdząc, że przekaz encyklopedycznej wiedzy powinien współcześnie ustępować pokazywaniu, jak swą wiedzę uaktualniać i samemu odnajdywać, w jaki sposób praktycznie zaaplikować hasła kreatywności lub interkulturowości w nauczaniu, jak nauczać kultury w powiązaniu z językiem w sposób poglądowy. To w taki sposób naukowcy de facto powinni uprawiać naukę: przechodzić od postaw pozytywistycznych do transformacyjnych.

Uleganie tendencjom neoliberalnym $w$ edukacji uniwersyteckiej jest aż nazbyt widoczne właśnie w zakresie kształcenia językowego i trudno się dziwić, że neofilolodzy znaleźli się na rozdrożu. Oczekuje się od nich praktycznego kształcenia zawodowego, podczas gdy oni chcieliby zaoferować jeszcze coś więcej: humanistyczną i kulturowo-językową ogładę. Takie idealistyczne dążenia mają swoje wysokie uzasadnienie wobec faktu, że urynkowienie edukacji, jak czytamy za Woodsem i Courpassonem oraz Cleggiem ${ }^{18}$ promuje pewne cele, założenia i praktyki, jednocześnie marginalizujące inne. Promuje bowiem traktowanie młodych ludzi jako potencjalne jednostki poddane działaniom ekonomicznym, u których takie umiejętności, jak elastyczność i zespołowość muszą być wkalkulowane obok atrybutów, które zachowają społeczną spójność (np. poczucie obywatelskiej odpowiedzialności). I chociaż takie cechy same w sobie, jak piszą wspomniani autorzy, nie są złe, to podejście edukacyjne, za pomocą którego są kształcone, i którego wizja wyłania się z doświadczanych do tej pory procedur reformy, sprowadza wizję edukacji do rozwijania człowieka w sposób ostatecznie zdefiniowany i wartościujący go w kategoriach instrumentalnego przystawania do danego systemu społeczno-ekonomicznego. Jak czytamy u ww. autorów, „dominującym celem, planowanym efektem dającym się zinstytucjonalizować w systemie, jest ukształtowanie ludzi $w$ taki sposób, że wewnętrznie i całym swoim jestestwem stają się przedsiębiorczą, instrumentalnie ukierunkowaną osobowością, obiektem racjonalności typu «wszystkie środki dozwolone o ile prowadzą do celu». Taka osobowość jest ceniona przez współczesne rynki i nowe formy biuro-

\footnotetext{
16 K. Bachmann, Co z tego, że wiedza, jeśli nie potrafia , "Gazeta Wyborcza”, 12-13 maja 2012, s. 19.

17 K. Modzelewski, Uniwersytet musi czuć problemy swojego czasu, [w:] Uniwersytet zaangażowany..., s. 56.

18 D. Courpasson, S. Clegg, Dissolving the Iron Cages? Tocqueville, Michels, Bureaucracy and the Perpetuation of Elite Power, "Organization” 2006, 13/3, s. 319-343; Alternative Education for the 21st Century Philosophies, Approaches, Visions, P. Woods, G. Woods Palgrave Macmillan.
} 
kracji"19. Gdzie zatem pozostawiono miejsce na rozwój wykraczający poza instrumentalną definicję funkcjonalnej przystawalności? Obrońcy elitarnej edukacji wyższej mają jawne podstawy do żalu i złości.

Nie jest moim zamiarem obrona wizji studenta oraz nauczyciela dostosowanych do nowego systemu, ani też trzymanie warty pod bramą twierdzy dotychczasowej formy edukowania neofilologicznego. Problemem każdego z nas jest obecnie znalezienie sposobu, $w$ jaki z tym nieuniknionym zjawiskiem i wbudowaną w nie sprzecznością sobie poradzić i jak się w nim odnaleźć. Według McCormacka ${ }^{20}$, potrzeba do tego sporej dawki wewnętrznej siły i umiejętności dokonywania refleksji. Na pewno refleksja nad własną praktyką jest podstawowym narzędziem pozwalającym na przyjęcie postawy krytycznej: albo wobec innowacji, podążając drogą mało konstruktywnej krytyki negatywnej, albo wobec tradycyjnych metod działania, przyjmując wyzwanie krytyki konstruktywnej i budującej. Pedagogika krytyczna, której współcześnie narzuconą rolą (także krytykowaną ze względu na niemoc wyjścia poza krąg jedynie demaskacji) jest między innymi obnażanie sytuacji problematycznych i odsłanianie dyskursywnie tworzonej rzeczywistości społecznej, mogłoby stanowić pożyteczne narzędzie dla skonsternowanych akademików. Nabierając najpierw samej świadomości krytycznej, mogliby z większym dystansem spojrzeć na zmieniającą się rzeczywistość edukacyjną, a potem własnym głosem (którego opisane badanie jest jakimś przykładem) przejść do etapu działania. Działaniem tym może być, jak pisze Gdula, drugi wariant krytyki, którym jest „otwarcie na polityczność i konieczność szukania sojuszników dla tworzenia świata, w którym żyłoby się lepiej większej liczbie aktorów"21. Tradycyjny bowiem, emancypacyjny rys teorii krytycznej, który w omawianym przypadku oznacza opór wobec utylitarnych procedur administracyjnych na rzecz obrony struktur i jakości elitarnej, może okazać się mało efektywny. Z czystej emancypacji lub nawet świadomości problemu, ku podniesieniu której zmierzało zaprezentowane badanie, nie zrodzi się bowiem od razu komfort i dobra praktyka. Należałoby może w sposób mniej emancypacyjny (w sensie jedynie buntowniczej demaskacji), a raczej systematyczny i racjonalny zbudować nową jakość. Ta racjonalność jednak musi być pozbawiona rysu dogmatyzacji i raczej opierać się na pewnej translacji racjonalności dawnej na racjonalność oczekiwaną współcześnie. Może powinnością nauczycieli języków obcych jest wejść na proponowany przez Zalewskąa22 postkonwencjonalny poziom świadomości własnej tożsamości zawodowej, pozwalający na dystans, refleksję i autonomię "do", a nie „od". Mając w ręku szczególny klucz do wielokulturo-

19 P.A. Woods, G. J. Woods, Introduction. Alternative Education for the 21st Century.Philosophies, Approaches, Visions, Palgrave Macmillan 2009, s. 2-3, tłumaczenie z j. angielskiego: B. Karpińska-Musiał.

20 A. McCormack, Classroom management: problems, strategies and influences in physical education, „European Physical Education Review” 1997, 3(2), s. 102-113; [w:] T.G. Ryan, op. cit., s. 5.

${ }^{21}$ M. Gdula, op. cit., s. 225.

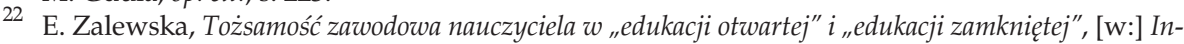
spiracje, otwarcia, krytyki w edukacji, red. E. Rodziewicz, Wyd. UG, Gdańsk 1995. 
wości, jakim jest język obcy, mają oni szansę podążyć takim rodzajem krytycyzmu, który Gdula opisuje jako „wzięcie odpowiedzialności za każde konkretne rozwiązanie jako za swój własny wytwór - możliwość pośród innych możliwości" ${ }^{23}$. Dzięki temu, być może będą współtworzyć "model uniwersytetu, który może pełnić funkcję kanału artykulacji w sytuacji otwarcia na polityczność, poszukiwanie sojuszników i tworzenie nowych form życia społecznego" 24 . W sytuacji tak realizowanej wizji uniwersytetu (być może zmodyfikowanej wersji idei Humboldta) Krajowe Ramy Kwalifikacji ani inne systemy kodów nie będą nikogo przerażały, gdyż będą po prostu czystą porządkującą formalnością, jednym z kanałów „artykulacji interesów", niezagrażającym meritum. A przede wszystkim niezagrażającym osobowościom uczestników zmiany. Aby to jednak stało się faktem, należy pamiętać o czysto ludzkim, psychologicznym aspekcie zmiany i podążania za nią, na który składa się wiele czynników. Ich analiza wykracza poza rozmiar i ramy tematyczne tego tekstu, zatem pozwolę sobie tylko tytułem zakończenia zacytować za Schwahn i Spady'm parę "regul” społecznego aspektu zmiany. Moje natomiast wnioski i refleksje oparte na przedstawionym badaniu niech posłużą za punkt wyjścia do rozwijania dalszych analiz w temacie stosunku do zmiany instytucjonalnej $\mathrm{w}$ kształceniu filologicznym.

Ludzie nie zmieniq się, dopóki nie potączy ich odpowiedni powód, by się zmienić;

Ludzie nie zmienia się, dopóki nie mają własnego udziału w zmianie;

Ludzie nie zmienia się, dopóki ich przywódcy nie pokaża, że sami traktuja zmianę poważnie;

Ludzie nie będa chętni zmianie, dopóki nie dostaną konkretnej wizji, co ta zmiana da im w wymiarze personalnym;

Ludzie nie dokonaja zmiany, ani też nie utrwala jej efektów, dopóki nie otrzymaja wsparcia organizacji w tej sferze25.

\section{Summary}

Two kinds of critical approach towards change among the academic staff at Foreign Language Faculties in Polish universities

The chapter addresses the issue of how the academics at foreign language faculties in Polish universities perceive selected aspects of change implemented by the Higher Education Reform. The main objective is to present the results of empirical research (online ques-

23 M. Gdula, op. cit., s. 224.

24 Ibidem, s. 225.

25 Na podstawie: C. Schwahn, W. Spady, Why Change Doesn't Happen and How to Make Sure it Does, „Educational Leadership. ASCD”, April 1998, vol. 55, no. 7, s. 45-47; P.M. Keys, Empowering Teachers in School and University Partnership, „Learning Communities. International Journal of Learning in Social Contexts", March 2008, no. 1, s. 53-67. 
tionnaire) based on opinions concerning work over adapting programs and syllabi of foreign philology studies to the requirements of KRK (National Qualification Framework). A secondary research objective was to observe whether the necessity to perform additional and demanding tasks to meet these requirements had induced teachers' reflexivity as to their own competencies and the quality of social, as well as professional work conditions. The two kinds of critical approach included in the title refer to the author's attempt to juxtapose a critical attitude of emancipatory character, which is demonstrated predominantly in the research results, with the signs of more transformative and constructive criticality: the one that would suggest building new quality on the new grounds. Foreign language teachers and researchers seem to be in the possession of tools that are especially helpful in meeting this challenge. Nevertheless, it is not yet clear how and to what extent they can be useful. The paper speaks with the voice of those academics who fight to maintain the high quality of philological education in the face of its massification and marketisation. 